\title{
Princípio da Ordem Pública no Indeferimento de Homologação de Sentenças Arbitrais ESTRANGEIRAS NO BRASIL: QUANDO A IMPRECISÃO PODE LEVAR À DESNECESSIDADE
}

Gustavo Ribeiro*

\begin{abstract}
1 Introdução. 2 A homologação de sentença arbitral estrangeira: aspectos introdutórios. 2.1 Aspectos históricos sobre os requisitos para a homologação de decisões estrangeiras. 2.2 Dos requisitos específicos em relação à sentença arbitral estrangeira. 3 Marcos teóricos: o princípio da ordem pública a partir do referencial de Jacob Dolinger. 3.1 Fluidez e imprecisão: a ordem pública como um princípio. 3.2 Instabilidade, contemporaneidade e fator exógeno. 3.3 Ordem pública interna, internacional e a verdadeiramente internacional. 4 Metodologia da pesquisa. 5 Análise dos resultados. 5.1 Caso Plexus v. Santana (SEC 967). 5.2 Caso Moreno v. Paulista (SEC 866). 5.3 Caso Subway v. HTP (SEC 833). 5. 4 Caso Indutech v. Algocentro (SEC 978). 5.5 Caso Biglift v. Transdata (SEC 11.593). 5.6 Caso Thyssenkrupp v. CSN (SEC 12.236). 6 Conclusões. Referências.
\end{abstract}

\section{RESUMO}

O artigo enfrenta a aplicação do princípio da ordem pública na homologação da sentença arbitral estrangeira pelo Superior Tribunal de Justiça. O tema é objeto de extenso debate ainda não totalmente consolidado na doutrina e nas cortes. Utilizando-se como marco teórico as concepções delineadas por Jacob Dolinger, desde 1979, indicando a dificuldade e a imprecisão na definição do conteúdo da ordem pública, sugere-se que os indeferimentos dos pedidos de homologação poderiam ter ocorrido sem qualquer alusão à violação à ordem pública. A base da pesquisa consistiu nas sentenças estrangeiras contestadas no período de 2006-2015. Dela, delimitaram-se seis casos cujos pedidos de homologação foram indeferidos pelo Superior Tribunal de Justiça na matéria. Aponta-se que as fundamentações poderiam ter se dado por remissão a critérios objetivos, por exemplo, a ausência de convenção arbitral, a incompetência do juízo arbitral e/ou

* Professor do Programa de Mestrado/Doutorado do UNICEUB-Brasília das disciplinas Conflito de Leis no Espaço, Análise Econômica do Direito e Direito Internacional Econômico. Professor na Graduação de Direito Internacional Privado. Obteve seu doutorado pleno em Direito Internacional pela Maurer School of Law, Indiana University Bloomington (EUA), como bolsista do programa CAPES/FULBRIGHT (revalidado UFSC, 2010). Mestre em Direito (UFSC, 2004). Bacharel em Direito (UFMG, 2002) e Ciência da Computação (UFMG, 1996). Advogado. E-mail:<gribeirobr@gmail.com>. 
falta de citação regular de uma das partes - hipóteses previstas na Lei de Arbitragem Brasileira e legislação relacionada. O recurso à ordem pública era desnecessário, embora reflita a complexidade do tema.

Palavras-chave: Sentença Arbitral Estrangeira. Homologação. Ordem Pública. Indeferimento. Superior Tribunal de Justiça.

\section{INTRODUÇÃO}

Traz-se, à tona, neste artigo, a questão sobre o significado da ofensa à ordem pública por ocasião da homologação de sentenças arbitrais estrangeiras, hipótese de indeferimento do pedido. ${ }^{1}$ Trata-se de apreciação que ocorre, normalmente, nos tribunais dos países homologantes (ad quem, host). No caso do Brasil, pelo Superior Tribunal de Justiça (STJ), ${ }^{2}$ como critério a ser superado no procedimento homologatório.

Decerto, a apreciação da ofensa (ou não) à ordem pública envolve o gênero decisão estrangeira: uma sentença estrangeira ou uma sentença arbitral estrangeira. Este artigo concentra-se na segunda espécie que é definida, de acordo com a Lei de Arbitragem Brasileira (LAB), ${ }^{3}$ como aquela que tenha sido proferida fora do território nacional. ${ }^{4}$

Parte-se do pressuposto da dificuldade inerente à definição em abstrato do que seja uma violação à ordem pública ou mesmo da necessidade de se buscar uma definição a priori, porém, vai-se além, tendo o artigo como hipótese principal que a problemática de definição e sua dificuldade em aplicá-la fazem que os indeferimentos dos pedidos de homologação com base em ofensa à ordem tenham se baseado em critérios objetivos, sem a necessidade de alusão à ordem pública. Os indeferimentos encontrariam amparo em outras exceções objetivas ou formais da legislação. ${ }^{5}$ Para se confirmar a hipótese, o artigo se desdobra em quatro seções, além desta introdutória.

Na segunda seção, investigam-se os critérios a que se submetem as decisões estrangeiras no procedimento homologatório. Verifica-se a origem mais que centenária desses critérios em nossa legislação, inclusive o da ofensa à ordem pública. Além disso, constatam-se, na evolução dos critérios, poucas alterações em termos de redação. Nessa mesma seção, analisam-se os critérios específicos que se aplicam à sentença arbitral estrangeira.

A seção subsequente (3) se edifica sobre o tratamento doutrinário da ordem pública. Elege-se como marco teórico o trabalho seminal do Professor Jacob Dolinger, apresentado no concurso à Cátedra de Direito Internacional Privado da Universidade do Estado do Rio de Janeiro. ${ }^{6}$ Nele, evidencia-se a complexa principiologia da ordem pública. De forma resumida, quatro seriam suas características: (i) a instabilidade; (ii) a contemporaneidade; (iii) o fator exógeno; (iv) e seu caráter internacional. 
A quarta seção, mais breve, expõe os aspectos da metodologia da pesquisa jurisprudencial empreendida. Além do critério espaço-temporal da análise, jurisprudência do STJ entre os anos de 2006 e 2015, detalham-se os parâmetros de pesquisa no sistema de busca e demais filtros aplicados às amostras colhidas.

Por fim, a partir do arcabouço doutrinal desenvolvido, na quinta seção, pesquisa-se de que forma o STJ vem aplicando a construção teórica delineada em seus julgados, buscando-se confirmar a hipótese proposta.

\section{A HOMOLOGAÇÃO DE SENTENÇA ARBITRAL ESTRANGEIRA: ASPECTOS INTRODUTÓRIOS}

A sentença arbitral estrangeira deve se submeter ao procedimento de homologação para que produza efeitos ou tenha seus efeitos - nela contidos - liberados, no Brasil. O interesse pelo procedimento surge, por exemplo, se se busca ressarcimento monetário, quando a parte vencida na arbitragem internacional se recusa a cumprir a decisão, mas possui bens em território brasileiro. Nesse caso, poderá a parte vencedora utilizar-se do procedimento homologatório que, uma vez deferido, possibilitará o uso do aparato estatal para fazer cumprir a sentença.

É pacífico que apenas uma ação ou procedimento de homologação é necessário, tendo o sistema de dupla homologação sido descartado no Brasil há mais de quinze anos, com a edição da $\mathrm{LAB},{ }^{7}$ isto é, a parte interessada não precisa homologar, inicialmente, a sentença arbitral no judiciário do país de origem da arbitragem, bastando apenas homologá-la no Brasil. Além disso, como igualmente apontado, o procedimento de homologação da sentença arbitral estrangeira não é uma peculiaridade da arbitragem, mas exigência da mesma sorte é aplicável às sentenças judiciais estrangeiras, qualquer que seja sua natureza. ${ }^{8}$

E é durante a homologação, em sede de juízo de delibação, que pode ocorrer a apreciação acerca da violação ou não à ordem pública. Podem-se distinguir, em realidade, quatro fases ou momentos em que a discussão sobre ordem pública pode ser suscitada: (i) inicialmente, pelo próprio árbitro internacional; (ii) em segundo lugar, pela eventual apreciação do Judiciário do foro de arbitragem; (iii) em seguida, no procedimento de homologação ou reconhecimento da sentença arbitral estrangeira (objeto deste estudo); e (iv) finalmente, na fase executória, pós-homologatória. ${ }^{9}$

De interesse direto deste artigo, concentramos na terceira fase (homologação), iniciando o estudo pela evolução do procedimento no Brasil.

\subsection{ASPECTOS HISTÓRICOS SOBRE OS REQUISITOS PARA A HOMOLOGAÇÃO DE DECISÕES ESTRANGEIRAS}

A previsão acerca da homologação de decisões estrangeiras é encontrada há mais de um século em nosso ordenamento. ${ }^{10}$ Marco relevante, a Lei n. ${ }^{0} 221$ (1894),$^{11}$ que versava sobre organização judiciária, transferia ao Supremo Tribu- 
nal Federal (STF) a competência para a homologação de decisões estrangeiras (judiciais ou arbitrais) e trazia critérios a serem aplicados. ${ }^{12}$

Ao analisarmos as redações originárias, no vernáculo à época, como o $\S 4$ do art. 12 da Lei n. ${ }^{\circ} 221$ de 1894 , lê-se que:

No processo de homologação observar-se-ha o seguinte: [...]

b) póde servir de fundamento para opposição:

$1^{\mathrm{o}}$, qualquer duvida sobre a authenticidade do documento ou sobre a intelligencia da sentença;

$2^{\circ}$, não ter a sentença passado em julgado;

$3^{\circ}$, ser a sentença proferida por juiz ou tribunal incompetente;

$4^{\circ}$, não terem sido devidamente citadas as partes ou não se ter legalmente verificado a sua revelia, quando deixarem de comparecer;

$5^{\circ}$, conter a sentença disposição contraria á ordem publica ou ao direito publico interno da União.

Os cinco requisitos, com variações na ordem (autenticidade e inteligência; trânsito em julgado; competência da autoridade prolatora; citação ou revelia legal; e não violação à ordem pública), fazem parte dos critérios atualmente vigentes, conforme abaixo. 


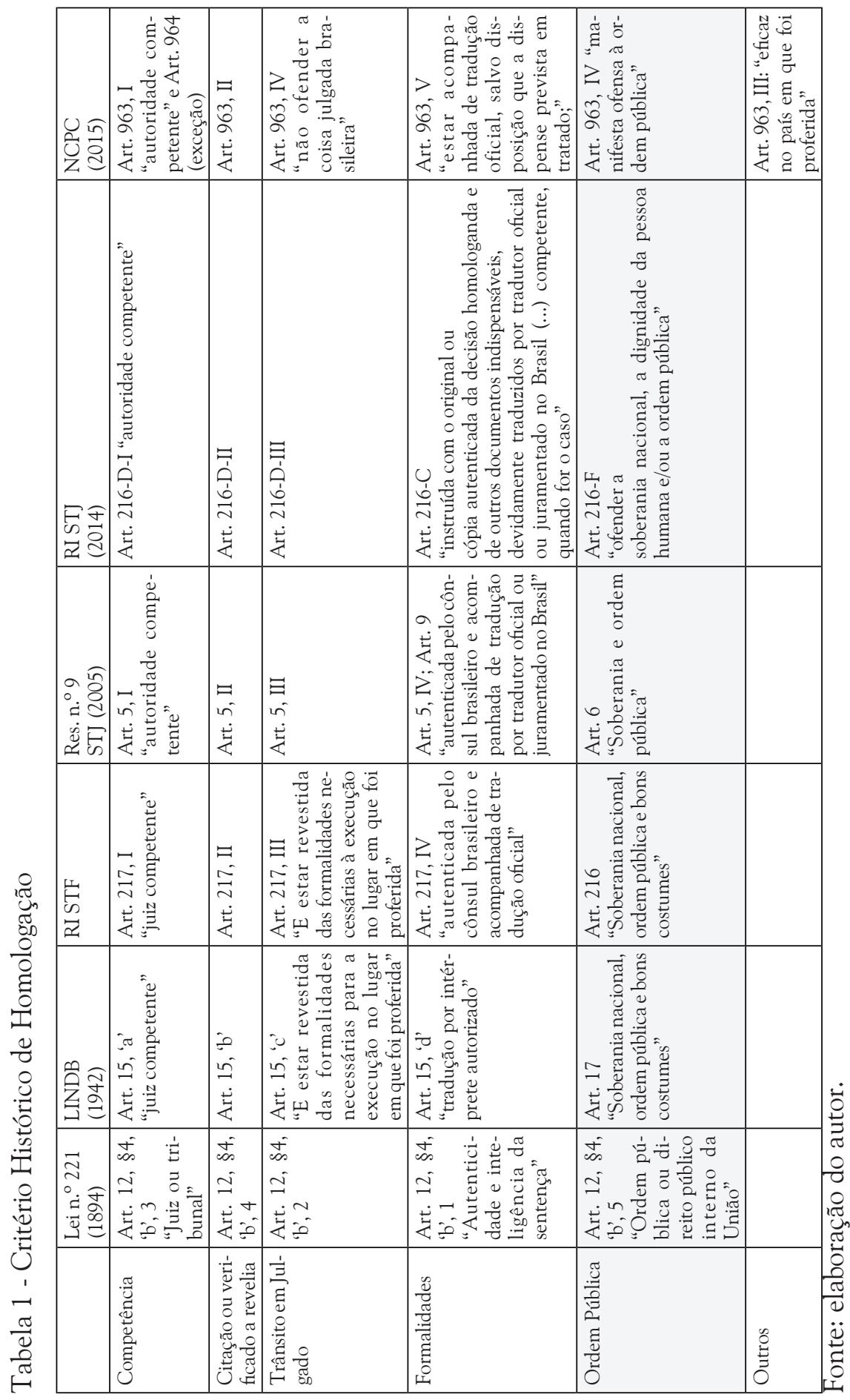


A Lei de Introdução ao Código Civil (LICC), atual Lei de Introdução às Normas do Direito Brasileiro (LINDB), ${ }^{13}$ por exemplo, prevê-os, desde 1942, pela combinação dos artigos 15 e 17. O Código de Processo Civil (CPC) de 1973, por sua vez, tratava muito mais dos aspectos da eficácia e da competência da decisão estrangeira: condicionava a eficácia da sentença proferida por tribunal estrangeiro à homologação do STF; e remetia o procedimento ao Regimento Interno do STF (art. 483 do CPC de 1973). O Regimento Interno do STF, a sua vez, mantinha os cinco critérios originais em seu arts. 216 e 217.

Com a transferência da competência do STF para o STJ para processar e julgar originariamente a homologação de sentenças estrangeiras (EC n. ${ }^{\circ}$ 45/2004), mantiveram-se, na essência, os cinco requisitos. O STJ, ao editar a Resolução no. 9/2005, em caráter transitório, praticamente repetiu os critérios em seus arts. 5 e 6. Mais recentemente, a incorporação da Resolução nº 9/2005 ao Regimento Interno do STJ (RI do STJ) reproduziu os mesmos critérios, com ligeiras modificações. ${ }^{14}$ Por fim, o CPC atual ${ }^{15}$ perfila critérios semelhantes ao longo de seu artigo 963, trazendo alguns dispositivos adicionais. ${ }^{16}$

Mas como ponto comum e conclusão intermediária desta seção, observa-se que os dispositivos originais relativos aos critérios de homologação se mantiveram, de forma geral e feitas as ressalvas anteriores, inalterados ao longo do tempo.

\subsection{DOS REQUISITOS ESPECÍFICOS EM RELAÇÃO À SENTENÇA AR- BITRAL ESTRANGEIRA}

Além dos cinco critérios supradestacados, a LAB e os tratados que o Brasil ratificou em matéria de arbitragem introduziram critérios adicionais como requisitos para a homologação. De acordo com a LAB: ${ }^{17}$

Art. 34. A sentença arbitral estrangeira será reconhecida ou executada no Brasil de conformidade com os tratados internacionais com eficácia no ordenamento interno e, na sua ausência, estritamente de acordo com os termos desta Lei.

Art. 36. Aplica-se à homologação para reconhecimento ou execução de sentença arbitral estrangeira, no que couber, o disposto nos arts. 483 e 484 do Código de Processo Civil [de 1973]. (grifos nossos)

Observando-se a combinação de dispositivos aplicáveis, verifica-se superposição de critérios, conforme abaixo. 


\section{Tabela 2 - Critério de Homologação de Sentenças Arbitrais}

\begin{tabular}{|c|c|c|c|}
\hline & $\begin{array}{c}\text { CNY } \\
(1958) \\
\text { Dec. } 4.311(2002)\end{array}$ & $\begin{array}{c}\text { LAB } \\
(1996)\end{array}$ & $\begin{array}{l}\text { RI STJ } \\
(2014)\end{array}$ \\
\hline Competência & $\begin{array}{l}\text { Art. V, 1, 'd' } \\
\text { "a composição da autoridade } \\
\text { arbitral ou o procedimento arbi- } \\
\text { tral não se deu em conformidade } \\
\text { com o acordado pelas partes" }\end{array}$ & $\begin{array}{l}\text { Art. } 38, \mathrm{~V} \\
\text { "a instituição da arbitra- } \\
\text { gem não está de acordo } \\
\text { com o compromisso arbi- } \\
\text { tral ou cláusula compro- } \\
\text { missória" }\end{array}$ & $\begin{array}{l}\text { Art. } 216 \text {-D-I "auto- } \\
\text { ridade competente" }\end{array}$ \\
\hline $\begin{array}{l}\text { Citação ou verificado } \\
\text { a revelia }\end{array}$ & $\begin{array}{l}\text { Art. V, 1, 'b' } \\
\text { "Réu não notificado da desig- } \\
\text { nação do árbitro, procedimento } \\
\text { de arbitragem, violação do con- } \\
\text { traditório" }\end{array}$ & Art. 38, III & Art. 216-D-II \\
\hline Trânsito em Julgado & $\begin{array}{l}\text { Art. V, 1, 'e' } \\
\text { "a sentença ainda não se tornou } \\
\text { obrigatória para as partes ou foi } \\
\text { anulada ou suspensa por auto- } \\
\text { ridade competente do país da } \\
\text { arbitragem" }\end{array}$ & Art. 38, VI & Art. 216-D-III \\
\hline Formalidades & $\begin{array}{l}\text { Art. IV, 1, 'a' e 'b' } \\
\text { "sentença e acordo original de- } \\
\text { vidamente autenticados ou uma } \\
\text { cópia dos mesmos devidamente } \\
\text { certificados }\end{array}$ & Art. 37, I e II & $\begin{array}{l}\text { Art. 216-C } \\
\text { "instruída com o ori- } \\
\text { ginal ou } \\
\text { cópia autenticada da } \\
\text { decisão homologanda } \\
\text { e de outros documen- } \\
\text { tos indispensáveis, } \\
\text { devidamente tradu- } \\
\text { zidos por tradutor } \\
\text { oficial (...)" }\end{array}$ \\
\hline Ordem Pública & $\begin{array}{l}\text { Art. V, 2, 'b' } \\
\text { "contrário à ordem pública } \\
\text { daquele país" }\end{array}$ & $\begin{array}{l}\text { Art. 39, II } \\
\text { "II - a decisão ofende a } \\
\text { ordem pública nacional." }\end{array}$ & $\begin{array}{l}\text { Art. 216-F } \\
\text { "ofender a } \\
\text { soberania nacional, a } \\
\text { dignidade da pessoa } \\
\text { humana e/ou a ordem } \\
\text { pública" }\end{array}$ \\
\hline $\begin{array}{l}\text { Incapacidade das } \\
\text { partes ou acordo in- } \\
\text { válido segundo lei } \\
\text { do foro }\end{array}$ & Art. V, 1, 'a' & Art. 38, I, II & --- \\
\hline $\begin{array}{l}\text { Sentença arbitral } \\
\text { proferida fora dos } \\
\text { limites da convenção } \\
\text { de arbitragem }\end{array}$ & Art. V, 1, 'c' & Art. 38, IV & --- \\
\hline
\end{tabular}

Fonte: elaboração do autor. 
Limitemo-nos, para demonstração, ao previsto em uma das mais importantes convenções sobre o tema: a Convenção de Nova Iorque sobre o Reconhecimento e a Execução de Sentenças Arbitrais Estrangeiras (CNY). ${ }^{18}$

Percebe-se que os requisitos do RI do STJ (e os da Resolução n. . 9/05, então vigentes para a maior parte da amostra analisada neste artigo) são "absorvidos" pelos requisitos da CNY e da LAB, sobressaindo-se critérios adicionais para a sentença arbitral estrangeira. Por exemplo, como formalidade ou requisitos objetivos, não apenas o original ou a cópia certificada da decisão arbitral devem constar no pedido de homologação, mas também a convenção arbitral (art. 37, II, da LAB). Ainda, se as partes na convenção de arbitragem eram incapazes, caso isso seja demonstrado pelo réu, poderá a homologação ser denegada (art. 38, I, da LAB).

Por fim, a ofensa à ordem pública é destacada em todos os instrumentos, com duas particularidades importantes em sede de arbitragem: (i) a ofensa deve se dar à luz da "ordem pública daquele país" (CNY) ou da "ordem pública nacional" (LAB); dispositivo que a doutrina sugere ser restritivo e que, em realidade, significaria uma "ordem pública internacional" ou "ordem pública nacional internacional"; ${ }^{19}$ e (ii) a existência de uma hipótese explícita sobre o que não configura ofensa à ordem pública.

No último caso, segundo a LAB:

Art. 39. [...] Parágrafo único. Não será considerada ofensa à ordem pública nacional a efetivação da citação da parte residente ou domiciliada no Brasil, nos moldes da convenção de arbitragem ou da lei processual do país onde se realizou a arbitragem, admitindo-se, inclusive, a citação postal com prova inequívoca de recebimento, desde que assegure à parte brasileira tempo hábil para o exercício do direito de defesa. ${ }^{20}$

Feita a incursão histórica e sistemática sobre os critérios relativos à homologação de decisões estrangeiras, passa-se ao estudo sobre a ordem pública na seção seguinte. Como já preconizado, o referencial teórico é construído a partir do trabalho do Professor Jacob Dolinger.

\section{MARCOS TEÓRICOS: O PRINCÍPIO DA ORDEM PÚBLICA A PARTIR DO REFERENCIAL DE JACOB DOLINGER}

Uma das principais obras dedicadas à ordem pública, na doutrina nacional, foi a tese apresentada pelo professor Jacob Dolinger para o concurso à Cátedra de Direito Internacional Privado da Universidade do Estado do Rio de Janeiro. ${ }^{21}$

Dolinger estudou, à época, a doutrina e a jurisprudência nacional e comparada. Nesse sentido, destacou, nas primeiras páginas de sua obra, a dificuldade de definição de ordem pública o que, para muitos, seria mesmo uma tarefa impossível. Houve os que tentaram conceituá-la e também aqueles que tentaram enumerá-la, mas, ao descobrirem sua relatividade, sua instabilidade 
e sua variabilidade no tempo e no espaço, todos acabaram reconhecendo que não há um conceito preciso de ordem pública. ${ }^{22}$

Aprofundemos os principais aspectos da ordem pública examinados na doutrina de Dolinger.

\subsection{FLUIDEZ E IMPRECISÃO: A ORDEM PÚBLICA COMO UM PRINCÍPIO}

Dificilmente a ordem pública pode ser reduzida a um conceito rígido, devido a sua constante mutação e indefinição, Dolinger advertia, entretanto, para o tratamento do tema no passado. Para isso, dividiu sua análise entre a doutrina "não-internacionalista" (de direito interno) e a de Direito Internacional Privado (DIPr).

Na primeira seara, a abordagem não era principiológica, mas rígida, pois era comum a indicação de leis de natureza de ordem pública relacionadas aos interesses essenciais do Estado e da coletividade. A caracterização dessas leis como de ordem pública se aproximava à ideia de leis absolutas ou imperativas - mencionadas em diversos códigos, como o francês e o suíço. ${ }^{23}$

De forma semelhante, na doutrina de DIPr (Savigny, Despagnet, Pillet), ocorreu essa tendência de caracterizar como inatas leis de ordem pública. Seriam estas coativas, cogentes, mandamentais ou proibitivas, diferentemente das leis supletivas ou permissivas. Ainda do ponto de vista prático, o Instituto de Direito Internacional e a Conferência de Haia recomendaram até mesmo, e com insistência, que as legislações internas enumerassem as suas leis de ordem pública. ${ }^{24}$ Dolinger ressaltava que:

Em certa época os autores pareciam concorrer entre si no esmero de enumerar maior número de leis desta natureza, chegando alguns a criar oito grandes grupos, cada um composto de várias categorias de leis que consideravam de ordem pública. ${ }^{25}$

Mas para Dolinger, a ordem pública é princípio e, como tal, é

[...] conceitual, filosófico, moral, indefinível, elástico, relativo, alterável, volúvel, sempre na dependência do conceito, da opinião, do sentimento, da sensibilidade média de um grupo social em determinada época que vai encontrar sua expressão clássica na sentença judicial. ${ }^{26}$

Dolinger se alinhou, assim, com o nível principiológico da ordem pública e afirmou que a ordem pública não é necessariamente característica inata da lei, mas princípio a ela externo. Tanto o é que "diversos institutos que ontem eram considerados de ordem pública deixam de sê-lo, sem que necessariamente ocorra qualquer alteração no direito positivo." ${ }^{\text {z }}$

Além disso, distinguiu Dolinger vários níveis de aplicação da ordem pública, dada a sua abstração. Partindo de uma gradação de tênue até gravíssima, Dolinger 
expôs os seguintes níveis de aplicação: um primeiro (tênue), que serviria para garantir o império de determinadas regras contra a vontade das partes; um segundo, no qual a ordem pública impede a aplicação de normas estranhas, por lhe serem chocantes, perturbadoras; um terceiro (mais elevado, ou de natureza gravíssima), quando um instituto estrangeiro é tão chocante e de tal intensidade que represente um escândalo para o foro, inclusive sobre uma situação já constituída e consumada alhures. ${ }^{28}$

Ainda sobre a imprecisão da ordem pública, no mesmo diapasão de Dolinger, Valladão, tratando dos efeitos e da conceituação da ordem pública, afirmava que

Denega-se, no Brasil, efeito ao direito estrangeiro que choca concepções básicas do foro, que estabelece normas absolutamente incompatíveis com os princípios essenciais da ordem jurídica do foro, fundados nos conceitos de justiça, de moral, de religião, de economia e mesmo de política, que orientam a respectiva legislação. É uma noção fluida, relativíssima, que se amolda a do sistema jurídico, em cada época, e fica entregue à jurisprudência em cada caso. ${ }^{29}$

Nota-se que vários autores posteriormente alinharam-se com a abstração de ordem pública. Strenger, por exemplo, verifica que a aplicação da ordem pública gera diversas controvérsias por ser difícil "a conciliação dos interesses nacionais ou transnacionais na determinação não só de certa metodologia exegética como, também, da identificação de uma essencialidade que permita bem definir a ordem pública." ${ }^{30}$ Nery Junior, ao seu passo, afirma que

Como a noção de ordem pública é conceito legal indeterminado, para que ganhe concretude, depende da atividade do juiz em cada situação concreta levada ao seu exame pelo jurisdicionado. Não é possível, desse modo, uma definição apriorística e exaustiva do seu conteúdo. ${ }^{31}$

Registram-se, ademais, posições intermediárias. Nadia de Araujo, por exemplo, parece admitir um sistema híbrido. Retomando a doutrina francesa, sugere que inexistir a aplicação da lei estrangeira no foro poderá ser objetada em função da imperatividade de uma norma interna (o que corresponderia à lei de ordem pública inata) ou ainda pela evicção da regra estrangeira contrária à ordem pública. No primeiro caso, não se chega nem mesmo a se discutir o conflito de leis. No segundo caso, o conflito surge. $O$ efeito final é o mesmo: a não aplicação do direito estrangeiro, e, talvez por isso, Araujo sugira que a pergunta que deve ser feita é aquela a respeito dos motivos que levariam à aplicação direta da lei do foro, no caso de sua imperatividade, em vez da aplicação à lei estrangeira pela regra de conexão. Nesse sentido, destaca o papel da Hermenêutica-Constitucional, da Teoria da Argumentação Jurídica (Dworkin, Perelman, Atienza, Alexy) e dos direitos fundamentais como guias mestras nessa tarefa. ${ }^{32}$

Hodiernamente, Dolinger parece ter mantido sua perspectiva inicial. Em obra mais recente, indica que, para impor o instituto da ordem pública, o aplicador do Direito deve utilizar como base o pensamento e a percepção de 
uma sociedade em uma determinada época. Essa ponderação realizar-se-á por meio do Poder Judiciário o qual aplicará o princípio da ordem pública: fenômeno social de extrema relevância que servirá de parâmetro para verificar o que ofende e o que não ofende o ordenamento jurídico nacional. A avaliação feita pela Justiça, portanto, afastará a aplicação de aspectos que violem a mente e a sensibilidade da sociedade. ${ }^{33}$

\subsection{INSTABILIDADE, CONTEMPORANEIDADE E FATOR EXÓGENO}

Como corolários de sua natureza principiológica, para Dolinger, a ordem pública possui três características evidentes: a instabilidade, a contemporaneidade e o fator exógeno. ${ }^{34}$

Sobre a instabilidade, sugere o autor que a ordem pública está intrinsecamente ligada a uma população estabelecida em um determinado tempo e um determinado espaço. Nesse contexto, populações em regiões territoriais diferentes possuem noções discrepantes do que venha a ser ordem pública. A própria evolução de suas gerações postula por uma ordem pública diversa do que a de seus antepassados. É esse o ponto chave da ordem pública, uma vez que sua conceituação está intrinsecamente ligada à instabilidade, sendo esse princípio colocado à disposição dos fenômenos sociais e ideários populacionais. ${ }^{35}$

Já a contemporaneidade, que aparecia de forma destacada em seu trabalho anterior ${ }^{36}$ faz que o magistrado responsável por julgar uma determinada lide se atente para a ordem pública vigente à época do julgamento; não à época em que ocorreu o fato ou ato jurídico, ou seja, é preciso decidir a questão sob a ótica do foro contemporâneo ao julgamento, aplicando ou não a lei estrangeira conforme a reação da população. Se a ordem pública foi alterada, propiciando uma maior liberalidade e receptividade, o fato passado, ocorrido com base na lei estrangeira, mesmo que não aceito pela ordem pública anterior, terá sua eficácia aceita na época de sua aplicação, dada a modificação da ordem pública. Por outro lado, a contemporaneidade também pode produzir o caminho inverso e conservador. Se um ato passado, homologado no foro anteriormente, se tornar ofensivo à ordem pública contemporânea, este não será reconhecido ou sequer produzirá efeitos. ${ }^{37}$

Por fim, ao se referir a fator exógeno, Dolinger retoma a concepção apresentada de que inexistem, aprioristicamente, leis de ordem pública, ou seja, refuta o doutrinador a existência de normas insubstituíveis e substituíveis. A ordem pública não está engessada nas linhas de uma norma jurídica, ela emana de um fator exógeno e deve ser separada de toda forma de lei, uma vez que a legislação em si não está imbuída da ordem pública, mas sim, respaldada pelo princípio, para rejeitar a lei estrangeira do foro. ${ }^{38}$

Resta, por fim, avaliarmos a distinção doutrinária entre a ordem pública interna, internacional e a verdadeiramente internacional ou universal, para que se feche o arcabouço teórico a ser utilizado na análise jurisprudencial que se segue. 


\subsection{ORDEM PÚBLICA INTERNA, INTERNACIONAL E A VERDADEI- RAMENTE INTERNACIONAL}

A doutrina de DIPr ocupou-se em dividir a ordem pública em duas dimensões: a interna, também denominada nacional ou relativa; e a internacional, que responderia pelos sinônimos de externa ou absoluta. ${ }^{39}$

Dolinger demonstrou, conquanto, as sutis variações encontradas em cada autor, o agrupamento da doutrina em duas grandes correntes: a que defendia a dicotomia (Despagnet e Weiss) e os contrários a ela (Bartin, Pillet, Fiore, Sommiéres, Louis Lucas). Haveria, ainda, classificações propugnando até mesmo pela existência de quatro categorias de ordem pública (Valery)..$^{40}$

De forma singular, Dolinger propôs uma categoria adicional de ordem pública: a verdadeiramente internacional, ou universal. Admitindo exceções, Dolinger ilustrava que todos os países civilizados entenderiam a poligamia, o incesto, a escravatura, entre outros, como institutos contrários a essa ordem. ${ }^{41}$ Afirmou, entretanto, que, se fosse a ordem pública verdadeiramente internacional, constituída tão somente desses itens, não nos ocuparíamos dela, eis que estaríamos no campo do Direito Internacional Público. Porém, na tentativa de defini-la, sugeriu que se trata daquela "que inspira uma determinada disciplina nas relações privadas internacionais, através de tratados e convenções." 42 Adicionou aos exemplos dessas normas aquelas pertencentes ao Acordo Geral sobre Tarifas e Comércio (GATT) do Fundo Monetário Internacional (FMI), a proteção da ecologia universal e do combate à corrupção internacional. Arrematava o conceito, da seguinte forma:

A ordem pública interna visa proteger a política, a moral e a economia de cada país; a ordem pública universal há de defender padrões de moralidade, de equidade e de igualdade entre os Estados para a manutenção de uma ordem em que, em última análise, estão interessados todos os membros componentes da sociedade internacional. ${ }^{43}$

Não parece fácil dissociarmos a ordem pública universal proposta por Dolinger com, justamente, o Direito Internacional Público. Pensamos que uma possível explicação para a distinção seria o momento no qual a obra de Dolinger foi escrita. Em 1979, pode-se dizer que o Direito Internacional Público estava, ainda, em termos de ratificações de convenções, em um estágio mais embrionário. Por exemplo, boa parte das convenções relativas ao combate à corrupção e à proteção ao meio-ambiente (matérias pertencentes a uma ordem internacional, segundo Dolinger) é posterior ao período de sua obra. Outra mencionada, como o GATT, possuía menos de 100 signatários à época, versus mais de 160, no âmbito da OMC, atualmente. Por outro lado, em posições mais recentes encontradas em seus manuais, Dolinger persevera pela distinção da categoria "ordem pública universal”, sem equipará-la ao Direito Internacional Público. 
Ressalta-se, ainda, a posição de Araujo quanto à existência de uma ordem pública internacional que, também a nosso ver, aproxima-se das razões de ser do Direito Internacional Público. A autora exemplifica com a Convenção Europeia de Direitos Humanos: instituidora de uma ordem pública europeia, embora não seja esta uma convenção de DIPr. ${ }^{44}$ Curiosamente, essa aproximação entre ordem pública internacional e ordem pública regional ou comunitária foi também assinalada por Dolinger em uma passagem singela, o que reforça a percepção de uma linha tênue a separar a ordem pública verdadeiramente internacional do Direito Internacional Público: "será desenvolvido o espírito das comunidades econômicas e políticas regionais, que criarão uma defesa à ordem pública comunitária, dentro do respeito à ordem pública internacional." ${ }^{35}$

Inobstante a falta de uma pacificação doutrinária sobre as dimensões da ordem pública, ${ }^{46}$ há de ser levado em conta ainda o contexto específico da arbitragem internacional. Como dissemos, a tônica da LAB e da CNY sugere que, ao se averiguar a ofensa à ordem pública (nacional ou do país de origem, respectivamente), estar-se-ia diante de algo mais restrito do que as expressões sugerem. No âmbito da homologação de sentenças estrangeiras, há que se conjugar regras de comércio internacional, respeito a uma decisão de natureza jurisdicionada transitada em julgado e a manutenção dos preceitos fundamentais do ordenamento do país. ${ }^{47}$

Antes de adentrarmos a análise da jurisprudência respectiva e como esse equilíbrio é buscado na jurisprudência, a seção seguinte expõe a metodologia utilizada na obtenção da amostra.

\section{METODOLOGIA DA PESQUISA}

A jurisprudência utilizada para o desenvolvimento do presente trabalho corresponde aos julgados do STJ, no intervalo temporal entre 2006 e 2015.48 Buscaram-se, assim, os casos julgados no período de dez anos, logo após a EC n. 45/04, que conferiu ao STJ a competência para julgar a homologação de sentenças arbitrais estrangeiras.

Mais precisamente, no sistema de consulta jurisprudencial do STJ,${ }^{49}$ foi realizada uma pesquisa por assunto. Além da referida delimitação temporal, os parâmetros utilizados para restringir a pesquisa ao vício da ordem pública na homologação da sentença arbitral estrangeira foram diversas combinações das palavras "SEC", "sentença estrangeira contestada", "arbitragem", "arbitr\$"(?) e "ordem pública". A combinação se justifica a fim de se obter uma amostra considerável de decisões. Descartaram-se, entretanto, eventuais decisões provenientes de recursos processuais sobre as ações originárias de homologação, como agravos, embargos de declaração ou semelhantes. O quadro abaixo resume os resultados obtidos: 


\begin{tabular}{|c|c|c|}
\hline Resultado Julgamento & $\mathbf{n}$ & Perc. \\
\hline Indeferidos & 11 & $19,3 \%$ \\
\hline Parcialmente Deferidos & 2 & $3,5 \%$ \\
\hline Deferidos & 42 & $73,7 \%$ \\
\hline Suspensos & 1 & $1,7 \%$ \\
\hline Extintos & 1 & $1,7 \%$ \\
\hline Total: & 57 & $100 \%$ \\
\hline
\end{tabular}

Fonte: elaboração do autor.

Como primeiro filtro na amostra obtida, concentramo-nos nos onze acórdãos proferidos nos quais houve o indeferimento da homologação, ou seja, nesses casos, acolheu-se, em algum grau, o indeferimento do pedido de homologação, supostamente com base em ofensa à ordem pública, objeto de interesse deste artigo.

No segundo filtro, resultante da análise dos onze acórdãos, a amostra foi reduzida para seis casos. Nestes havia, concomitantemente, indeferimento do pedido de homologação e alguma discussão relativa ao significado da ordem pública, ou seja, descartaram-se cinco casos na qual a decisão foi capturada pelo sistema de busca, mas, ao se avaliar qualitativamente o acórdão, não havia maiores aclaramentos sobre o significado da ordem pública.

Reconhecem-se, igualmente, os limites da pesquisa pela delimitação da análise aos casos envolvendo apenas indeferimento de pedidos. Os casos de deferimento podem igualmente proporcionar compreensão do significado da ordem pública, ainda que a alegação não tenha sido acatada. As conclusões do artigo devem, assim, ser relativizadas. A expansão de análise sobre a amostra, em análises futuras, permitirá reavaliações da hipótese proposta bem como servirá como mitigador da referida limitação.

\section{ANÁLISE DOS RESULTADOS}

As seções seguintes trazem a análise qualitativa da amostra de seis casos. Estes foram dispostos em ordem cronológica, e os nomes das partes aparecem de forma reduzida, como forma de simplificação da leitura.

Em linha com a proposta do artigo, intenta-se expor que, face à complexidade e fluidez da ordem pública de difícil apuração, o acatamento do indeferimento das homologações recaiu sobre outras hipóteses, de cunho objetivo. As decisões, em outras palavras, poderiam ter sido as mesmas, sem recurso ao dito princípio. 


\subsection{CASO PLEXUS V. SANTANA (SEC 967)}

Nesse pedido de homologação, julgado em 2006, tem-se a Plexus Cotton como requerente, sociedade constituída e existente de acordo com as leis de Liverpool e, como requerida, a Santana Têxtil, empresa constituída no Brasil. A decisão arbitral foi proferida pela Liverpool Cotton Association (LCA), condenando a requerida, entre outras coisas, a pagar a quantia de aproximadamente 232 mil dólares..$^{50}$

O pedido de homologação é uma renovação de pedido anterior - possibilidade prevista no artigo 40 da LAB -, alegando a requerente que o fazia por ter sido a denegação anterior proferida apenas com vícios formais. ${ }^{51}$

Duas questões se desdobram em relação à ordem pública. A primeira diz respeito aos efeitos da ação de homologação anterior e a produção ou não de coisa julgada, na qual a ordem pública aparece de forma incidente. Nesse sentido, o Ministro Relator aponta que:

A decisão do STF [anterior ao caso corrente], de forma clara, reconheceu a inexistência de cláusula compromissória e, conseqüentemente, a impossibilidade absoluta da homologação, por o julgado ter sido proferido por juízo incompetente. Essa questão, como decidida, não apreciou questões formais. Situa-se na aplicação de princípio de ordem pública para indeferir a homologação. Ela está, hoje, revestida, a meu entender, com força da coisa julgada. Impossível revê-la, salvo em sede de ação rescisória. ${ }^{52}$

Conclui o Ministro Relator que a decisão anterior não se amparou apenas em questões formais. Justificar-se-ia justamente pela aplicação do princípio da ordem pública para indeferir a homologação, ou seja, adotou o Ministro Relator a mesma linha do STF de que havia um conjunto de dispositivos violados; entre eles, os artigos 37-II (existência de convenção de arbitragem), 38-I (capacidade das partes), 38-II (invalidade da convenção de arbitragem) e, igualmente, o artigo 39-II (ofensa à ordem pública nacional) da LAB. Consequentemente, o pedido de homologação em curso deveria ser extinto sem julgamento do mérito. Vencido, restou o Ministro Relator, entretanto, nessa preliminar, passando a analisar o novo pedido. ${ }^{53}$

Nesse ponto, surge novamente a discussão sobre a ordem pública, com base na nova documentação carreada nos autos. Constata o Ministro relator não ter conseguido, mais uma vez, identificar a existência de cláusula compromissória aceita pela parte requerida, concluindo que:

A discussão está centrada na ausência da manifestação voluntária por escrito da requerida em aceitar a cláusula arbitral. É, portanto, ofensa à ordem pública por ir de encontro a princípio insculpido em nosso ordenamento jurídico que exige aceitação expressa das partes para submeterem a solução dos conflitos surgidos nos negócios jurídicos contratuais privados à arbitragem (grifos nossos)..$^{54}$ 
Neste ponto, expressa o Ministro Relator que a ofensa à ordem pública decorre da ausência de manifestação da requerida em aceitar a arbitragem. Dos trechos reproduzidos da decisão anterior, vê-se que, como fizera o STF, entende o Ministro Relator que fica aniquilada a autonomia da vontade das partes, princípio basilar da arbitragem. Não podendo se cogitar em aceitação tácita de juiz arbitral, constituindo-se ofensa à ordem pública. ${ }^{55}$

Poder-se-ia cogitar que se trata de um caso em que a violação à ordem pública foi embasada além dos requisitos objetivos ou formais enumerados na LAB ou na Res. 9 do STJ, vigente à época. Nesse condão, haveria, ao que tudo indica, uma convenção de arbitragem (art. 37-II da LAB), supostamente válida segundo o direito inglês (art. 38-II da LAB). Porém, a alegação de que as leis inglesas permitiriam uma cláusula de arbitragem dentro de um contrato para legitimar o foro arbitral foi rechaçada. Não existiria no ordenamento jurídico pátrio a correspondente regra apontada do direito inglês. Assim, a ofensa à ordem pública estaria coerente com a doutrina apresentada.

Entretanto, é igualmente plausível entender que a falta de uma convenção de arbitragem resulta em incompetência do juízo arbitral, sendo hipóteses claras e satisfatórias para a denegação da homologação. É o que sugerimos ocorrer em boa parte dos casos seguintes, a seguir analisados.

\subsection{CASO MORENO V. PAULISTA (SEC 866)}

Nessa ação homologatória, julgada em 2006, a Oleaginosa Moreno, sociedade constituída de acordo com as leis argentinas, requereu a homologação de sentença arbitral proveniente da The Grain and Feed Trade Association (GAFTA) contra a Moinho Paulista (requerida). A decisão arbitral condena, entre outras coisas, a requerida ao pagamento de cerca de US\$ 1.6 milhões de dólares. ${ }^{56}$

Relembrou o Ministro Relator que o controle judicial da sentença arbitral estrangeira está limitado a aspectos de ordem formal, não podendo ser apreciado o mérito do arbitramento. Neste sentido, ao analisar os aspectos factuais do caso, entendeu ser incontroverso que os aludidos contratos foram negociados verbalmente entre as partes, o que a própria requerida admite e informa. Entendeu, ainda, que o fato de os contratos firmados entre as partes terem sido celebrados verbalmente não impediria, por si só, a estipulação de cláusula compromissória. Em consonância com a CNY (Artigo 2, II) e a LAB (Artigo 4, §1), bastaria que houvesse uma cláusula compromissória pactuada de forma expressa e escrita em outro documento referente ao contrato originário ou em correspondência apartada. ${ }^{57}$

Estabeleceu, então, o Ministro Relator que a ausência de dita cláusula compromissória impunha o reconhecimento da incompetência do juízo arbitral e a ofensa à ordem pública. Mencionou, ainda, a posição do então Procurador-Geral da República, Geraldo Brindeiro e a SEC 6753/UK, julgada pelo STF em 2002, no mesmo sentido. Quer-se dizer: a ausência de cláusula compromissória 
escrita impede aferir a competência do juízo prolator, configurando ofensa à ordem pública nacional. ${ }^{58}$

Na linha da análise anterior, entendemos que a inexistência de convenção arbitral válida (art. 37, II da LAB) e a consequente incompetência do juízo arbitral são hipóteses por si só suficientes para que a homologação fosse indeferida.

\subsection{CASO SUBWAY V. HTP (SEC 833)}

A SEC 833/US de relatoria inicial da Ministra Eliana Calmon e de relatoria, para o acórdão final, do Ministro Luiz Fux, foi julgada em agosto de 2006. Esta envolvia pedido de homologação de sentença arbitral proferida pela Associação de Arbitragem Americana (AAA-EUA). Figurava como requerente a sociedade empresária Subway Partners, com sede nos Estados Unidos da América, e como requerida a HTP, também conhecida como Subway Brasil. O acórdão não faz referência expressa à quantia prevista na condenação, mas apenas ao fato de que a parte credora obteve decisão, rescindindo o contrato e estabelecendo as sanções contratualmente previstas. ${ }^{59}$

À decisão da Ministra Relatora, em 2005, seguiu-se pedido de vistas do Ministro Fux. Reconheceu o Ministro que não se tratava de discussão sobre a existência ou não de convenção de arbitragem, mas muito mais o fato de o processo ter corrido à revelia e não ter havido prova inequívoca da citação. Ainda, segundo o Ministro, seria cediço, na jurisprudência do STJ, que a homologação de sentença estrangeira reclama prova de citação válida da parte requerida mediante carta rogatória, fazendo alusão ao art. 217, II, do RISTF (correspondente ao art. 38, III da LAB). Não toca o Ministro, diretamente, sobre a questão da ofensa à ordem pública. ${ }^{60}$

Em realidade, o Acórdão toca o tema da ordem pública em dicta. No voto-vista do Ministro Nilson Naves, fez-se referência à manifestação do curador especial da requerida no sentido de ele mesmo apontar, pelo parágrafo único do artigo 39 da $\mathrm{LAB}$, que a referida lei afasta a invocação de ofensa à ordem pública nacional se ocorre efetiva citação da parte no Brasil, nos moldes da convenção de arbitragem ou da lei processual do país onde se realizou a arbitragem. ${ }^{61}$

A decisão gira, como se disse, muito mais sobre outras questões, como a ausência de prova inequívoca de qualquer citação. ${ }^{62}$ Assim, concordamos com o rumo tomado de que, ao configurar claramente uma hipótese enumerada pelos artigos 38 e 39 da LAB, distinta da ordem pública, não há de se fazer a ela referência ou discuti-la, segundo nossa perspectiva.

\subsection{CASO INDUTECH V. ALGOCENTRO (SEC 978)}

No caso relatado pelo Ministro Carvalhido, julgado em dezembro de 2008, a requerente (Indutech) requer a homologação de sentença arbitral estrangeira 
proferida pela LCA, em valores aproximados de 416 mil dólares. A arbitragem decorre de descumprimento contratual, em face da requerida (Algocentro).$^{63}$

Em seu relatório, o Ministro Relator ressaltou que a requerida foi citada por meio de carta de ordem, não oferecendo contestação. Ante esse fato, nomeou-se curador - Defensoria Pública da União - para a parte. A defesa alegou, entre outros, a inexistência de anuência contratual da requerida para a instauração de processo arbitral. O Ministro Relator, em seu voto, fundamentou, com base nos arts. $3^{\circ}, 4^{\circ}, \S \S 1^{\circ}$ e $2^{\circ}$ e art. $5^{\circ}$ da Lei $9.307 / 96$, a inexistência expressa e inequívoca da parte em aceitar a estipulação de juízo arbitral para solução de eventuais conflitos entre os contratantes. Apontou, ademais, que a anuência da parte poderia ter sido realizada em contrato ou em instrumento apartados aptos a demonstrar a inequívoca manifestação da parte em aderir à cláusula arbitral.

In casu, todavia, ao que se tem dos autos, a cláusula de eleição do juízo arbitral contida no contrato de fornecimento de algodão cru (fl. 57) e seu termo aditivo (fl. 66), bem assim a indicação de árbitro em nome da requerida (fl. 529), não possuem assinatura ou visto qualquer de Algocentro Armazéns Gerais Ltda, ressentindo-se, assim, da sua indispensável anuência ao juízo arbitral ${ }^{64}$ (grifos originais).

Assim, na sequência, fundamentou o julgador que, em face da ausência de comprovação de que a requerida se utilizou da autonomia da vontade para instaurar como órgão de solução de litígios o juízo arbitral, é incabível a homologação da sentença arbitral estrangeira. Desrespeitar-se-ia o princípio da ordem pública, nos termos do art. $4^{\circ}$, parágrafo $2^{\circ}$, da Lei $9.307 / 96$ e dos arts. $5^{\circ}$, I e $6^{\circ}$, da Resolução n. 9/05 do STJ..$^{65}$

Mais uma vez, tem-se que a ofensa à ordem pública ocorreu em concomitância à violação de outro critério objetivo elencado pela LAB, que se resume à falta de competência do juízo arbitral - crítica esta que já fizemos e retomaremos adiante.

\subsection{CASO BIGLIFT V. TRANSDATA (SEC 11.593)}

Apesar do decurso de tempo entre o último caso analisado (2008) e o corrente (2015), a discussão contida no Acórdão guarda semelhança com as anteriores. Narra-se que a empresa Biglift (requerente) solicitou homologação de sentença estrangeira, com base em contrato de afretamento de viagem (2011). Pelo contrato, obteve no juízo arbitral a condenação da requerida para pagar o valor de aproximadamente 100 mil dólares, em função de atraso (tecnicamente conhecido como demurrage) no transporte de transformadores de energia entre portos brasileiros, com aplicação da lei inglesa como regente na relação jurídica. ${ }^{66}$

Entre vários pontos discutidos, o Ministro Relator se concentrou na incompetência do juízo arbitral (art. 15 da LINDB). Para chegar a essa conclusão, 
relembrou que a requerente sustentava a validade da cláusula de foro arbitral e lei inglesa, mas, ao apreciar a validade, o Julgador entendeu que a opção arbitral e do direito material aplicável deveria se submeter à regra de regência da LINDB (art. 9 da LINDB). Havia um contrato, e ele foi executado, embora destaque o julgador que, mais do que não ter havido destaque à escolha da arbitragem ou faltado uma rubrica, "a inteira minuta do contrato deixou de receber a assinatura das partes”. E, segundo o $\$ 1$ do art. 4 da LAB (resultado material da regra de conflito, pressupõe-se), deveria a cláusula compromissória ter sido estipulada por escrito. ${ }^{67}$

Na sequência, o Acórdão cita como matéria pacificada no STJ, de acordo inclusive com entendimento anterior do STF, a necessidade de cláusula compromissória escrita e assinada para que se pudesse exigir das partes submissão à arbitragem. ${ }^{68}$ As remissões são feitas, entre outras, às SEC 967, SEC 978, SEC 866, SEC 885, analisadas anteriormente.

O Acórdão, entretanto, não faz recurso expresso, como estamos a arguir, de que se trata de um indeferimento com base na violação à ordem pública. Apenas por remissão, foi o caso associado à, supostamente, violação à ordem pública. Ao nosso ver, de forma coerente com a hipótese proposta, concentra-se o Acórdão na questão da incompetência do juízo arbitral o que, por si só, seria suficiente para o indeferimento.

\subsection{CASO THYSSENKRUPP V. CSN (SEC 12.236)}

Por fim, também em dezembro de 2015, o STJ se defrontou com caso envolvendo a Thyssenkrupp (requerente) e CSN (requerida) em pedido de homologação de sentença arbitral estrangeira. A decisão havia sido proferida pela CCI, na Alemanha, por árbitro único, condenando a requerida ao pagamento de aproximadamente 760 mil dólares por inadimplemento contratual relativo ao fornecimento de bobinas de aço. ${ }^{69}$

Não adentramos nas minúcias do caso quanto às relações societárias entre requerente e requerida e os contratos entabulados. Destacamos apenas que, dos contratos analisados pelos STJ (Offtake de 1999; Termination de 2004), concluiu-se pela validade do último, que determinava a resolução de controvérsia por três árbitros da CCI. Fazendo menção às SEC 11.529, SEC 10.658 e SEC854, conclui o julgador pela incompetência do juízo arbitral originário - singular e não uma tríade. ${ }^{70}$

Com isso, indeferiu-se o pedido com base nos artigos 216-C, 216-D e 216-F do Regimento Interno do STJ e do art. 15 da LINDB. Como estamos a sustentar, admissível que o indeferimento se desse apenas pela hipótese da incompetência, sem qualquer remissão à ordem pública, como feito (art. 216-F do RI do STJ). 


\section{CONCLUSÕES}

Este artigo teve como proposta contrapor teoria e jurisprudência acerca da aplicação do princípio da ordem pública nos indeferimentos de homologação de sentenças arbitrais estrangeiras.

Utilizou-se o instrumental teórico de Dolinger, desenvolvido desde 1979, para a referida apreciação. Nele, a ordem pública é descrita como principiológica, fluida e imprecisa, entre outros. Ao nosso ver, decorreria daí uma elevada dificuldade em apreciá-la, fazendo com que, nos indeferimentos com base na dita ofensa, estivesse-se simplesmente diante do não cumprimento de outros critérios objetivos enumerados pela LAB. Não haveria talvez a necessidade de se discutir ordem pública naqueles casos. A ordem pública, em si, estaria pouco enfrentada sob o aspecto da instabilidade, contemporaneidade, exogeneidade, gradação (tênue até gravíssima) ou internacionalidade.

Nos seis casos analisados qualitativamente, percebemos que o indeferimento poderia ter se concentrado apenas na ausência da convenção de arbitragem (art. 37-II da LAB), que guarda relação com falta de competência da autoridade arbitral estrangeira (art. 5, I, da antiga Res. 9 do STJ, art. 216-D-I do RI do STJ e art. 15, 'a', da LINDB), ou na falta de citação (art. 5, II, da antiga Res. 9 do STJ, art. 216-D-II do RI do STJ e art. 15, 'b', da LINDB). A análise dos casos mais recentes da amostra, SEC 11.593 e SEC 12.236, aliás, sugere que os requisitos formais foram suficientes, não tendo sido necessário adentrar em uma análise aprofundada da violação à ordem pública (embora tenha ela sido referenciada de forma oblíqua). Deve-se ter, ao mesmo tempo, precaução com uma afirmação mais categórica a respeito, em função das limitações da pesquisa.

Por exemplo, primeiramente, foram apenas seis os casos efetivamente analisados no qual havia a concomitância violação à ordem pública e indeferimento do pedido. Uma melhor apreciação do tema deve levar em conta os casos nos quais houve a arguição da violação à ordem pública, mas o deferimento total ou parcial da homologação - situações não tratadas no artigo. Estar-se-ia, nesses casos, revelando-se, quiçá, o que não se configura violação à ordem pública. A própria LAB traz uma dessas hipóteses, talvez prenunciando um caminho que a jurisprudência possa seguir, delimitando-se o não ser, face à dificuldade do ser. Em segundo lugar, uma apreciação mais ampla da ordem pública requer uma ampliação do objeto, para se incluírem as sentenças judiciais estrangeiras; caminho não trilhado por razões de delimitação do tema. Da mesma forma, a jurisprudência comparada na matéria, por meio da análise do dispositivo correlato da CNY em diversas jurisdições.

Decerto, a pesquisa merece continuidade, não só pelo desafio da análise ampliada, em si, mas também em função do crescente aumento das arbitragens internacionais envolvendo partes brasileiras, com o potencial de serem, em algum momento, apreciadas pelo STJ. 


\section{REFERÊNCIAS}

ABBUD, André de Albuquerque Cavalcanti. Homologação de sentenças arbitrais estrangeiras. São Paulo: Atlas, 2008.

AGRIPLIANO, Ricardo de Carvalho. Ordem pública e processo. São Paulo: Atlas, 2011.

ALMEIDA, Ricardo Ramalho. Arbitragem comercial internacional e ordem pública. Rio de Janeiro: Renovar, 2005.

ARAUJO, Nadia de. Direito Internacional Privado: teoria e prática brasileira. 2. ed. Rio de Janeiro: Renovar, 2004.

BÖCKSTIEGEL, Karl-Heinz. Public Policy as a Limit to Arbitration and its Enforcement. Revista de Arbitragem e Mediação, São Paulo, v. 6, n. 21, p. 163-175, abr.jun. 2009.

BRASIL. Decreto-Lei 4.657, de 04 de setembro de 1942. Lei de Introdução às normas do Direito Brasileiro. (Redação dada pela Lei no 12.376, de 2010. Rio de Janeiro, 4 set. 1942. D.O.U 9.9.1942. (LINDB).

BRASIL. Lei 221, de 20 de novembro de 1894. Completa a organisação da Justiça Federal da Republica. Rio de Janeiro, 20 nov. 1894. D.O.U. 25.11.1894.

BRASIL. Lei 9.307, de 23 de setembro de 1996. Dispõe sobre a arbitragem. Brasília, 23 set. 1996. D.O.U. 24.9.1996 (LAB).

BRASIL. Lei 13.105, de 16 de março de 2015. Código de Processo Civil. Brasília, 16 mar. 2015. D.O.U. 17.3.2015. (NCPC).

BRASIL. Superior Tribunal de Justiça. Sentença Estrangeira Contestada (SEC) n. ${ }^{\circ}$ 833. Relator. Min. Eliana Calmon. Relator para Acórdão: Luiz Fux. Corte Especial, Julgado em 16.08.2006. D.J. 30.10.2006.

BRASIL. Superior Tribunal de Justiça. Sentença Estrangeira Contestada (SEC) n. ${ }^{\circ}$ 866. Relator: Felix Fischer. Corte Especial, Julgado em 17.05.2006. D.J. 16.10.2006.

BRASIL. Superior Tribunal de Justiça. Sentença Estrangeira Contestada (SEC) n. ${ }^{\circ}$ 967. Relator: José Delgado. Corte Especial, Julgado em 15.02.2006. D.J. 20.03.2006.

BRASIL. Superior Tribunal de Justiça. Sentença Estrangeira Contestada (SEC) n. ${ }^{\circ}$ 978. Relator. Hamilton Carvalhido. Corte Especial, Julgado em 17.12.2008. D.J. 05.03.2009.

BRASIL. Superior Tribunal de Justiça. Sentença Estrangeira Contestada $\mathbf{n}^{\mathbf{o}}$ 11.593. Relator: Benedito Gonçalves. Corte Especial, Julgado em 12.12.2015.

BRASIL. Superior Tribunal de Justiça. Sentença Estrangeira Contestada n. ${ }^{\mathbf{o}}$ 12.236. Relator: Mauro Campbell Marques. Corte Especial, Julgado em 16.12.2015. 
COSTA, José Augusto Fontoura; TUSA, Gabriele. Expectativas e âmbito da aplicabilidade da nova lei de arbitragem. In: CASELLA, Paulo Borba (Coord.). Arbitragem: a nova lei brasileira (9.307/96) e a praxe internacional. São Paulo: LTr, 1996.

CREMADES, Bernardo M.; CAIROS, David J. Orden público transnacional en el arbitraje internacional: cohecho, blanqueo de capitales y fraude contable. Revista de Direito Bancário do Mercado de Capitais e da Arbitragem, São Paulo, v. 6, n. 20, p. 283-308, abr./jun. 2003.

DOLINGER, Jacob. A evolução da ordem pública no Direito Internacional Privado. Rio de Janeiro: Graf. Luna, 1979. Tese apresentada à Egrégia Congregação da Universidade do Estado do Rio de Janeiro para o concurso à Cátedra de Direito Internacional Privado.

DOLINGER, Jacob. Direito Internacional Privado: parte geral. 9. ed. Rio de Janeiro: Renovar, 2008.

GONÇALVES, Eduardo Damião. Artigo V (inciso II). In: WALD, Arnoldo; LEMES, Selma Ferreira (Coord.). Arbitragem comercial internacional: a convenção de Nova Iorque e o direito brasileiro. São Paulo: Saraiva, 2011.

LEMES, Selma Ferreira; TIBURCIO, Carmen. Homologação de sentença estrangeira: ausência de citação. Revista de Arbitragem e Mediação, São Paulo, v. 4, n. 13, p. 211-238, abr./jun. 2007.

MANGE, Flavia Foz; AYMONE, Priscila Knoll. Arbitragem e poder judiciário. Relatório do grupo de trabalho: homologação de sentença arbitral estrangeira. Direito GV Working Papers, São Paulo, p. 73-78, set. 2010. Disponível em: < http://bibliotecadigital.fgv.br/dspace/bitstream/handle/10438/7713/ Working\%20paper\%2061.pdf?sequence=1>. Acesso em: 15 jul. 2016.

NERY JUNIOR, Nelson. Competência concorrente - jurisdição internacional - jurisdição brasileira. Soluções Práticas. Revista dos Tribunais, São Paulo, v. 3, p. 773, set. 2010.

SAMTLEBEN, Jürgen. Histórico da arbitragem no Brasil. In: CASELLA, Paulo Borba (Coord.). Arbitragem: a nova lei brasileira (9.307/96) e a praxe internacional. São Paulo: LTr, 1996.

STRENGER, Irineu. Aplicação de normas de ordem pública nos laudos arbitrais. Revista dos Tribunais, São Paulo, v. 75, n. 606, p. 9-12, abr. 1986.

VALLADÃO, Haroldo. Direito Internacional Privado. 5. ed. Rio de Janeiro: Freitas Bastos, 1980. v. 1.

\footnotetext{
Vejam-se Tabelas 1 e 2, na Seção 2 para as correspondentes hipóteses legais.

2 Conforme o art. 105, I, i da Constituição Federal, a partir da Emenda Constitucional n. ${ }^{\circ}$ 45/2004, a competência para a homologação de sentenças estrangeiras e a concessão de exequatur às cartas rogatórias passou a ser do Superior Tribunal de Justiça (STJ), em substituição ao Supremo Tribunal Federal (STF).

3 BRASIL. Lei 9.307, de 23 de setembro de 1996. Dispõe sobre a arbitragem. Brasília, 23 set. 1996.
} 
$4 \mathrm{LAB}$, art. 34, parágrafo único: "Considera-se sentença arbitral estrangeira a que tenha sido proferida fora do território nacional."

5 Não se ignora que outros autores trabalharam hipóteses e constatações semelhantes. Vejam-se: MANGE, Flavia Foz; AYMONE, Priscila Knoll. Arbitragem e poder judiciário. Relatório do grupo de trabalho: homologação de sentença arbitral estrangeira. Direito GV Working Papers, São Paulo, p. 73-78, set. 2010. Disponível em: <http://bibliotecadigital.fgv.br/dspace/bitstream/handle/10438/7713/Working\%20 paper\%2061.pdf?sequence=1>. Acesso em: 15 jul. 2016. AGRIPLIANO, Ricardo de Carvalho. Ordem pública e processo. São Paulo: Atlas, 2011. p. 49-51. Porém, entende-se que neste artigo, expande-se o período da pesquisa, bem como se propõe, a partir do marco teórico definido no trabalho de Dolinger, consequências em termos da utilização da ordem pública; qual seja, a de que a dificuldade de sua aplicação conduz a um metauso do princípio.

6 DOLINGER, Jacob. A evolução da ordem pública no direito internacional privado. Rio de Janeiro: Graf. Luna, 1979. Tese apresentada à Egrégia Congregação da Universidade do Estado do Rio de Janeiro para o concurso à Cátedra de Direito Internacional Privado.

7 Tanto na redação anterior, quanto na atual, conforme a Lei n ${ }^{\circ} 13.129$, de 2015, prevê-se, na essência, que para ser reconhecida ou executada no Brasil, a sentença arbitral estrangeira está sujeita à única homologação (conforme a redação atualizada do art. 35 da LAB). Sobre este ponto, na doutrina, vejam-se: ARAUJO, Nádia de. Direito internacional privado: teoria e prática brasileira. 2. ed. Rio de Janeiro: Renovar, 2004. p. 286. RECHSTEINER, Beat. Direito internacional privado: teoria e prática. São Paulo: Saraiva, 2010. p. 334.

8 Por fim, a questão da sentença judicial de qualquer natureza, para que se registre, remete à discussão sobre a dispensa da homologação de sentença judicial estrangeira meramente declaratória de estado de pessoa, tal qual preconizava a redação do parágrafo único do art. 15 da LINDB, porém revogado em 2010. (DINIZ, Maria Helena. Lei de introdução ao código civil brasileiro interpretada. São Paulo: Saraiva, 2011. p. 425-429; RECHSTEINER, op. cit., p. 317-318).

9 Para autores que também diferenciam cada fase: ALMEIDA, Ricardo Ramalho. Arbitragem comercial internacional e ordem pública. Rio de Janeiro: Renovar, 2005. p. 26-27; 67; e COSTA, José Augusto Fontoura; TUSA, Gabriele. Expectativas e âmbito da aplicabilidade da nova lei de arbitragem. In: CASELLA, Paulo Borba (Coord.). Arbitragem: a nova lei brasileira (9.307/96) e a praxe internacional. São Paulo: LTr, 1996. p. 206.

10 SAMTLEBEN, Jürgen. Histórico da arbitragem no Brasil. In: CASELLA, Paulo Borba (Coord.). Arbitragem: a nova lei brasileira (9.307/96) e a praxe internacional. São Paulo: LTr, 1996.

11 BRASIL. Lei 221, de 20 de novembro de 1894. Completa a organização da Justiça Federal da República. Rio de Janeiro, 20 nov. 1894. D.O.U. 25.11.1894.

12 SAMTLEBEN, op. cit., p. 49-50.

13 BRASIL. Decreto-Lei 4.657, de 04 de setembro de 1942. Lei de Introdução às normas do Direito Brasileiro. (Redação dada pela Lei no 12.376 , de 2010. Rio de Janeiro, 4 set. 1942. D.O.U 9.9.1942. (LINDB).

14 Por exemplo, a inclusão da ofensa à dignidade da pessoa humana como hipótese de indeferimento do pedido. Porém, por não ter objeto deste artigo, não é desenvolvida esta problemática.

15 BRASIL. Lei 13.105, de 16 de março de 2015. Código de Processo Civil. Brasília, 16 mar. 2015. D.O.U. 17.3.2015. (NCPC).

16 Por exemplo, sobre medidas de urgência e dispensa de homologação em caso de sentença estrangeira de divórcio consensual que, igualmente, estão fora do escopo deste artigo.

17 BRASIL. Lei 9.307, de 23 de setembro de 1996. Dispõe sobre a arbitragem. Brasília, 23 set. 1996.

18 Gonçalves indica que "devido à semelhança dos dispositivos - CNY e LAB - neste quesito, aliado ao fato de que, por alguma razão, os julgadores no Brasil tendem a relegar ao segundo plano a aplicação de tratados internacionais, mesmo após a ratificação da CNY pelo Brasil, o STF, num primeiro instante, e o STJ, em seguida, continuaram aplicando a LBA quando a referência à CNY teria sido mais apropriada”. GONÇALVES, Eduardo Damião. Artigo V (inciso II). In: WALD, Arnoldo Wald; LEMES, Selma Ferreira (Coord.). Arbitragem comercial internacional: a convenção de Nova Iorque e o direito brasileiro. São Paulo: Saraiva, 2011.

19 Para uma discussão e sumário de distintos autores, AGRIPLIANO, op. cit., p. 51-55.

20 O dispositivo admite que o critério para citação do réu, residente ou domiciliado no Brasil, seja estipulado na convenção de arbitragem ou na lei processual do país onde se realizou a arbitragem. Afasta-se, assim, uma defesa comum observada na jurisprudência, em que a ré residente ou domiciliada no Brasil invocava a ofensa à ordem pública por não ter sido citada por carta rogatória. 
21 Em sua introdução, Dolinger relembra que não foi o primeiro a se dedicar ao tema. Haveria, até então, quatro estudos; dois deles, como monografias para concursos de livre docência (Gama e Silva e Otávio Mendonça) e duas outras obras monográficas (Luiz Araújo Corrêa de Brito e Elmo Pilla Ribeiro). DOLINGER, op. cit., Introdução: IX e X.

22 Ibidem, p. 3.

23 Ibidem, p. 8-11.

24 Ibidem, p. 13-14.

25 Ibidem, p. 15.

26 Ibidem, p. 10-11.

27 Ibidem, 1979, p. 8-12.

28 Ibidem, 1979, p. 40-42.

29 Valladão relembrava a tradição francesa na qual a ordem pública se encontrava enunciada de modo específico e rígido. Porém assumiu, em realidade, sua preferência pelo sistema tradicional (fluido), dada a variabilidade do conceito, que seria dificultado com qualquer texto rígido. VALLADÃO, Haroldo. Direito internacional privado. 5. ed. Rio de Janeiro: Freitas Bastos, 1980. v. 1. p. 496-497.

30 STRENGER, Irineu. Aplicação de normas de ordem pública nos laudos arbitrais. Revista dos Tribunais, São Paulo, v. 75, n. 606, p. 9, abr. 1986.

31 NERY JUNIOR, Nelson. Competência concorrente - jurisdição internacional - jurisdição brasileira. Soluções Práticas. Revista dos Tribunais, São Paulo, v. 3, p. 773, set. 2010.

32 ARAUJO, op. cit., p. 95-111.

33 DOLINGER, Jacob. Direito internacional privado: parte geral. 9. ed. Rio de Janeiro: Renovar, 2008. p. 394.

34 Ibidem, p. 397-402.

35 Dolinger, por exemplo, exemplifica com o divórcio a instabilidade e relatividade da ordem pública. $\mathrm{Na}$ França, o divórcio foi recepcionado pela legislação revolucionária e pelo Código de Napoleão em 1804. Posteriormente, ele foi abolido por lei em 1816, voltando a ser implantado no ordenamento jurídico em 1884. O Brasil, por outro lado, nessa época, reprimia e inadmitia o divórcio, com base no ideário de que o matrimônio era insolúvel, conforme se pode constatar pelas Constituições de 1937, 1937, 1946 e 1967/69, vindo esse instituto a ser permitido em 1977, por meio de uma Emenda Constitucional, e, posteriormente, por lei ordinária (Ibidem, p. 397-398).

36 DOLINGER, op. cit., 1979, p. 118-125.

37 DOLINGER, op. cit., 2008, p. 398-400.

38 Ibidem, p. 400-403.

39 Dolinger localizou em Esperson, doutrinador italiano, a origem da dicotomia, embora grande parte da doutrina tenha atribuído a distinção conceitual a Charles Brocher. Tal qual desenvolvida à época, a ordem pública interna era aquela aplicada apenas aos nacionais de um território e a externa aos nacionais e estrangeiros, sendo a distinção baseada no enfoque pessoal (DOLINGER, op. cit., 1979, p. 26-28). Para discussão contemporânea, ABBUD, André de Albuquerque Cavalcanti. Homologação de sentenças arbitrais estrangeiras. São Paulo: Atlas, 2008. p. 203-216.

40 No plano doutrinário brasileiro, os autores adeptos à concepção dicotômica de ordem pública foram Rodrigo Otávio, Beviláqua, Espínola, Valladão e Strenger. Agrupando-se, contrariamente, Batalha, Tenório, Amílcar de Castro, Gama e Silva e Pilla Ribeiro (DOLINGER, op. cit., 1979, p. 28-31; 36-37).

41 Ibidem, p. 237-246.

42 Ibidem, p. 247.

43 Ibidem, p. 251.

44 ARAUJO, op. cit., p. 116-118.

45 DOLINGER, op. cit., 1979, p. 250.

46 Para discussões correlatas, vejam-se: BÖCKSTIEGEL, Karl-heinz. Public policy as a limit to arbitration and its enforcement. Revista de Arbitragem e Mediação, São Paulo, v. 6, n. 21, p. 163-175, abr./jun. 2009 (discutindo os diversos conceitos de public policy no contexto europeu e os diversos momento de sua apreciação); CREMADES, Bernardo M.; CAIROS, David J. Orden público transnacional en el arbitraje internacional. Revista de Direito Bancário do Mercado de Capitais e da Arbitragem, São Paulo, v. 6, n. 20, p. 283-308, abr./jun. 2003. (discutindo ordem pública transnacional envolvendo corrupção e fraude).

47 AGRIPLIANO, op. cit., p .55.

48 Tendo sido 01 de janeiro de 2006 e 31 de dezembro de 2015 o intervalo delimitado no sistema de pesquisa quanto à publicação das decisões. 
49 Disponível em: <http://www.stj.jus.br/SCON>. Acesso em: 15 jul. 2016.

50 BRASIL. Superior Tribunal de Justiça. Sentença Estrangeira Contestada n. ${ }^{\circ}$ 967. Relator: José Delgado. Corte Especial, julgado em 15.02.2006, p. 2.

51 Ibidem, p. 4.

52 Ibidem, p. 12-13.

53 Ibidem, p. 14. A base da extinção seria o artigo 267, V do CPC de 1973. Entretanto, o Acórdão não indicou os motivos determinantes para não ter sido prevalecente a tese, do Ministro Relator, de extinção da ação.

54 Ibidem, p. 16.

55 Ibidem, p. 16.

56 BRASIL. Superior Tribunal de Justiça. Sentença Estrangeira Contestada n. ${ }^{\circ}$ 866. Relator: Felix Fischer. Corte Especial, julgado em 17.05.2006, p. 3.

57 Ibidem, p. 7-8.

58 Ibidem, p. 9-10.

59 BRASIL. Superior Tribunal de Justiça. Sentença Estrangeira Contestada n. ${ }^{\circ}{ }^{833}$. Relator: Luiz Fux. Corte Especial, julgado em 16.08.2006, p. 5; 10). Curiosamente, o pedido estava acompanhado da chancela (homologação) do Tribunal Distrital dos Estados Unidos da América, Distrito de Connecticut - órgão do poder judiciário daquele país, cumprindo-se exigência anterior à LAB; qual seja, o sistema de dúplice homologação, não mais necessário após a vigência da LAB.

60 Ibidem, p. 22.

61 Ibidem, p. 27.

62 Veja-se LEMES, Selma Ferreira; TIBURCIO, Carmen. Homologação de sentença estrangeira: ausência de citação. Revista de Arbitragem e Mediação, São Paulo, v. 4, n. 13, p. 211-238, 2007.

63 BRASIL. Superior Tribunal de Justiça. Sentença Estrangeira Contestada n. ${ }^{\circ}$ 978. Relator: Hamilton Carvalhido. Corte Especial, julgado em 17.12.2008, p. 3.

64 SEC n. ${ }^{\circ} 978,2008$, p. 6.

65 Ibidem.

66 BRASIL. Superior Tribunal de Justiça. Sentença Estrangeira Contestada n. ${ }^{\circ}$ 11.593. Relator: Benedito Gonçalves. Corte Especial, julgado em 12.12.2015, p. 2.

67 Ibidem, p. 10-11.

68 Ibidem, p. 11-14.

69 BRASIL. Superior Tribunal de Justiça. Sentença Estrangeira Contestada n. ${ }^{\mathbf{0}}$ 12.236. Relator: Mauro Campbell Marques. Corte Especial, julgado em 16.12.2015, p. 5-6. 2

70 Ibidem, p. 9-16.

THE PRINCIPLE OF PUBLIC ORDER IN THE DENIAL OF RECOGNITION OF FOREIGN ARBITRAL AWARDS IN BRAZIL: WHEN IMPRECISION MAY LEAD TO UNNECESSITY

\section{ABSTRACT}

This article addresses the application of the principle of public order in the recognition of foreign arbitral awards by the Brazilian Superior Court of Justice. The topic is the object of an open-ended debate involving doctrine and courts. Using the ideas developed by Jacob Dolinger since 1979 as a theoretical framework, indicating the complexity and imprecision of the contents of public order, this article suggests that the denial of recognition in the analyzed cases could have been established without any mention of violations to public order. The basis for 
the research was the foreign arbitral awards whose recognition was discussed between the years of 2006 and 2015; of these, six cases were identified as those in which the Superior Court of Justice denied recognition. This article suggests that the reasoning supporting the decisions could have been based on objective criteria: for instance, the absence of an arbitration convention, the incompetence of the arbitral tribunal and/or the absence of proper party notification - all such criteria are present in the Brazilian Law on Arbitration and its related statutes. Resorting to the argument of public order was unnecessary, although it reflects the complexity of the topic.

Keywords: Foreign arbitral award. Recognition. Public order. Denial. Superior Court of Justice

Submetido: 8 ago. 2016

Aprovado: 27 set. 2016 